Editorial

\title{
Gypsy Policy and Roma Activism: From the Interwar Period to Current Policies and Challenges
}

\author{
Elena Marushiakova * and Vesselin Popov \\ School of History, University of St Andrews, KY16 9BA, St Andrews, UK; E-Mails: emp9@st-andrews.ac.uk (E.M.), \\ vp43@st-andrews.ac.uk (V.P.) \\ * Corresponding author
}

Submitted: 17 March 2020 | Published: 4 June 2020

\begin{abstract}
The editorial introduces the key ideas of this thematic issue, which originated within the European Research Council project 'Romalnterbellum. Roma Civic Emancipation between the Two World Wars.' The period between WWI and WWII in the region of Central, Southeastern and Eastern Europe was an era of worldwide significant changes, which marked the birth of the Roma civic emancipation movement and impacted Roma communities' living strategies and visions about their future, worldwide. The aspiration of this thematic issue is to present the main dimensions of the processes of Roma civic emancipation and to outline the role of the Roma as active participants in the historical processes occurring in the studied region and as the creators of their own history. The editorial offers clarifications on the terminology and methodology employed in the articles included in this issue and their spatial and chronological parameters while also briefly introducing the individual authored studies of this issue.
\end{abstract}

\section{Keywords}

Central Europe; civic emancipation; Eastern Europe; equality; Gypsy Policy; inclusion; Interwar Period; nation-state; Roma Activism; Southeastern Europe

\section{Issue}

This editorial is part of the issue "Gypsy Policy and Roma Activism: From the Interwar Period to Current Policies and Challenges" edited by Elena Marushiakova (University of St Andrews, UK) and Vesselin Popov (University of St Andrews, UK).

(C) 2020 by the authors; licensee Cogitatio (Lisbon, Portugal). This article is licensed under a Creative Commons Attribution 4.0 International License (CC BY).

\section{Introduction}

This thematic issue addresses the history of the Romaknown at that time under different local denominations, translated into English as Gypsies-in the period between WWI and WWII in Central, Southeastern and Eastern Europe, and its impacts in current policies and activism.

The period in analysis represented an era of significant changes worldwide, encompassing the breakdown of old Empires, the re-drawing of borders, the beginning of new-world relations on a macro-level and new interethnic relations on micro-levels, huge movement of populations, the birth of new nation states, the rise of nationalism and internationalism, exchange of populations, civil wars and more. All these events not only marked the beginning of a new stage in world history but, on a microlevel, had a direct impact on living strategies and visions for the future of Roma communities worldwide. It was also the time when, for the first time, different solutions, strategies and models for social inclusion of Roma communities were proposed and applied by different actors, including Roma themselves.

Clarifications on the terminology and methodology employed in the articles in this thematic issue of Social Inclusion are due, as well as on their spatial and chronological parameters. We start with the latter.

\section{Spatial and Chronological Scope}

The spatial scope of the articles included in this issue is fixed as the region of Central, Southeastern and Eastern 
Europe. This definition is not based on purely geographical reasons, but on historical and geopolitical criteria. Until the early 20th century, these were the lands of the three great Empires-Austro-Hungarian, Ottoman and Russian-where, after their disintegration, numerous new nation-states emerged. This is also the region where, at the time, the processes of Roma civic emancipation emerged and developed. Finland's short-lived membership within the Russian Empire (1809-1917) proved sufficient in developing the Roma emancipation movement in sync with a common paradigm for this entire region, which justifies the inclusion of Finland, part of the Scandinavian historical region, in one of our articles. At the same time, some other countries in the region (such as Austria, Albania, Lithuania, Estonia), where no written evidence has yet been found concerning the process of Roma civic emancipation, are absent.

The chronological scope of the issue is not determined by specific dates but according to respective historical eras. In the original idea of this thematic issue, the chronological limits were intended to be the two World Wars. Nevertheless, it also includes reflections on today's Roma policy, activism and failures of strategies for social inclusion which simply cannot be realized without a fuller understanding of the region's history during the interwar period.

Along with presenting results from current historical research, the aim of this thematic issue is to reflect and respond to anxieties coming from parallels with current failures of policies for inclusion, increased ethnic hatred and clashes and unfulfilled promises for equality. However, based on existing and newly discovered historical sources, and due to the purpose of the individual articles themselves, it appeared necessary to go beyond the range of our intended chronological limits: namely, the interwar period. In order to better explore and explain the processes of Roma civic emancipation, there was an evident need to start at the roots, wherein the first manifestations of Roma civic emancipation took us further back in time. As seen from the articles, though to some extent conditional, the inceptive time is set, in some cases, in the mid-19th century. This was when modern nationalism rapidly developed, especially after the revolutions of 1848 , and when the processes of Roma civic emancipation began to take root.

In this thematic issue we have attempted to look at these processes while avoiding the 'trap' of Orientalism (Said, 1995) and Balkanism (Todorova, 2009). For us, Roma are not characterised by a "belated modernisation" (Jusdanis, 1991), belated even in comparison with surrounding nations in Eastern Europe. Just the opposite: For us, they are part of the modernisation of the region viewed through the lenses of "multiple modernities" (Eisenstadt, 2000). Roma emancipation as a national building process is here perceived as part of a global social process of re-arrangement of group solidarities, as a by product of modernity (Todorova, 2005). Roma emancipation as a process is strengthened by the ethnic solidarity that inevitably emerges among groups which are relegated to inferior positions in a cultural division of labour (Hechter, 1975).

The end caesura of our focus is the WWII, which fundamentally changed the worldwide social and political order and greatly influenced the processes of Roma emancipation. The end of the WWII marks the beginning of a new and quite different historical era.

This frontier however is not chronologically fixed due to a number of circumstances. Different countries became involved in the war at different times and, in some of them, the processes of Roma civic emancipation continued to evolve for some time also under new social, economic and cultural conditions brought about by the conflict. In addition, some of the materials presented (the memories of participants in the events, for example) are of a later date, even when they describe the events of the interwar period. We also extend our chronological boundaries to include the contemporary dimension, i.e., the striking similarities between Roma emancipation in the interwar period and current concerns.

Chronological boundaries are not to be perceived literally. They are not absolute, since both the historical roots of particular processes and their later appearances, and present-day manifestations are reflected upon.

\section{On Terminology}

The two key terms used in the literature, source material and now analysed in the articles in this issue are 'Roma' and 'Gypsies.' There is no need to pay attention here to the public debate surrounding the use of these terms, in which two discourses (political and academic) are wrongly mixed; this debate is closely correlated with the development of contemporary Roma activism and is under the decisive influence of current political structures at (mainly European) international and national levels (Marushiakova \& Popov, 2018, pp. 385-418). In this case, we take a pragmatic approach and consider it sufficient enough to briefly explain the principles underlying the use of the two key terms in the thematic issue.

The guiding principle that defines the use of the term 'Gypsies' is historical. Since the Middle Ages, Roma communities have lived in the region of Central, South-Eastern and Eastern Europe, and were denoted by the surrounding population with different names. Such denominations include 'AӨıpyavol' (Byzantine Empire, Greece), 'Kıbtı' and 'Çingene' (Ottoman Empire, Turkey), 'Цигани' (Serbia, Bulgaria, Yugoslavia), 'Țigani' (Romania), 'Zigeuner' (Austro-Hungarian Empire, Austria), 'Cigányok' (Hungary), 'Cikáni' and 'Cigáni' (Czechoslovakia), 'Cyganie' (Poland), 'Цыгане' (Russian Empire, USSR, Russian Federation), 'Čigonai' (Lithuania), 'Čigāni' (Latvia), 'Mustalased' (Estonia), 'Mustalainen' (Finland) and more. Over time, and especially after WWI, when the old empires collapsed and new ethnic-nationstates emerged in the region, some of these names turned into official terms and became political denom- 
inations of the Roma communities in their respective countries. All these denominations are usually translated into English with the ethnonym 'Gypsies.'

From our point of view however, this is not an adequate translation; the word 'Gypsies,' in the Englishspeaking world, including the scholarly jargon, is used to denominate diverse nomadic communities regardless of their ethnic origins and identity (Hancock, 2010, pp. 95-96). The term, as well as all its equivalents in local languages, is used in referrence to all these communities throughout history, and certainly so during the period in analysis, from the mid-19th century to the end of WWII, despite its 'inappropriateness.' Modifying this in historical sources would mean de facto rewriting and falsifying history (including the quoted historical sources) from a contemporary perspective.

The Roma activists themselves, in the period of the birth of their civic emancipation movement, except when they wrote in the Romani language, also used these terms, and in their struggles for the civic emancipation of their own community they proceeded from the official discourse set out in their respective countries precisely. Without adequately reflecting on this discourse, one could not understand the first attempts to change it, especially in Romania and Finland, by replacing the designation 'Gypsies' with 'Roma,' which began during this period. In the end, in the translation of such local terms into English, the articles use the word Gypsies simply because a more adequate term does not presently exist.

For these reasons, the designation 'Gypsies' is used in this thematic issue in the historical sense, i.e., when presenting historical realities. The designation 'Roma' is, however, used as well, when speaking from the contemporary point of view, wherein the movement for Roma civic emancipation is considered globally, and as a movement that is still evolving today.

\section{The Contributions}

Within one single thematic issue, the overall dimensions of the processes of Roma civic emancipation cannot be covered in its entirety, and perhaps it is even less possible to present all their specific manifestations. Our aspirations are more modest: Through this issue we intend to represent the diversity of these processes, and in different countries of the Central, Southeastern and Eastern Europe region because, in each of them, they differ in certain and more or less clearly expressed specific traits (which does not, however, exclude their commonality as a whole).

Each of the articles included in this issue deals with a different dimension of the processes of Roma civic emancipation in an individual country of the framed region. The only exception is that of Marushiakova and Popov (2020), who present the attitude of the new Roma civic elite towards nomadism of part of the Roma in the region. The article clearly illustrates how, years before contemporary scholars started to abandon nomadism as the pri- mordial and inherent feature on which Romani identity is built, this Roma civic elite rejected the colonial approach which exoticized their community.

Šarenac (2020) pays attention to the participation of Roma from Serbia in the ranks of the army, which is a turning point from which Roma civic emancipation actually begins. This participation is perceived by Roma themselves, as well as by the entire macro-community, as an important sign for their social integration as part of the Serbian civic nation, in which Roma seek their equal place while preserving their community identity.

Turning to the much more general and comprehensive plan of the newly created post-war Yugoslavia, Zahova (2020) elaborates on this topic further by presenting the work and vision for the future of the Roma community of one of the most important Roma visioneers, Svetozar Simić.

Marinov (2020) reveals yet another issue related to the processes of the Roma civic emancipation by focusing on the Bulgarian society of the interwar period and the integration of Roma, which, the author shows, is just about existing negative social stereotypes as it is about the reaction of the new Roma civic elite and their fight against these stereotypes.

Two of the articles in the issue are devoted to the processes of Roma civic emancipation in Romania. Matei (2020) presents the overall dimensions of these processes in context, revealing the existing dependencies and alliances and outlining the leading trends and directions in their development. Ploscariu (2020), on the other hand, studies the introduction of the new evangelical churches among the Roma, a process that has become especially important today since belonging to Evangelical movements and churches is now one of the leading trends in the life of the Roma in the whole region.

Hajnáczky's article (2020) is dedicated to a hitherto almost unknown and unexplored phenomenon, namely Gypsy music associations in Hungary. The emphasis here is not so much on presenting their activities in protecting the professional interests of Gypsy musicians, but on the overall incorporation of Gypsy music as an integral part of the Hungarian musical culture, which proves to be an important factor in the overall process of social integration of Roma in the Hungarian nation.

Gontarek (2020) presents one specific aspect of the processes of Roma civic emancipation-the so-called 'Gypsy Kings' in Poland. This represents a historical curiosity as well a media phenomenon with no further advancement. The author's focus is not so much on the verisimilitude of the publicly proposed ideas for the creation of a 'Gypsy state' in different parts of the world but, rather, in presenting the competitions and alliances as documented in the Gypsy Kings' struggles for shaping the future of their communities, including the emergence and development of the very idea of a national Roma state.

While in other countries in the region the movement for Roma civic emancipation generally did not succeed to attract the active support of the authorities, which, 
in most cases, treated it negligently, in the Soviet Union of the 1920s and 1930s the situation was quite different. Within the framework of the common national policy of affirmative action (Martin, 2001), the new Soviet Roma elite was given the opportunity to turn part of its ideas into state policy and to participate actively in its implementation. The article by Shapoval (2020) presents a comprehensive picture of the Soviet state's cultural policy toward the Gypsies and assesses it as Romani Cultural Renaissance. Chernykh (2020) reveals another aspect of the common affirmative policy of the Soviet state toward Gypsies - the development of economic activities in the Keldarari group through the system of artels (small productive cooperatives) as a form of social inclusion of Roma.

The final article in this thematic issue, by Roman (2020), is dedicated to the specific case of the development of Roma civic emancipation processes in Finland, a country which does not presently belong to the region under research. Here, the development of these processes begins along the path of the evangelical churches and, as said above, this direction of development continues to be relevant to this day. A fascinating element in this study is connected with the combination of individual elements, many of which have parallels in examples from other countries and which, once again, underline the importance of the country's historical legacy.

\section{Conclusion}

One of the important features of this issue is that all the articles are largely based on materials written by the Roma themselves. This sets a basis for a new, holistic approach in studying the main dimensions of the processes of Roma civic emancipation in the region of Central, Southeastern and Eastern Europe. It clearly outlines the role of the Roma as active participants in the historical processes occurring in the studied region and as the creators of their own history. Our ambition is that this issue will contribute to a change in the leading paradigms of Romani Studies and Roma will cease to be presented only as passive victims of certain governmental policies towards them. Rather, they will become active participants in the presentation and analysis of their own historical processes.

\section{Acknowledgments}

This entire thematic issue of the journal Social Inclusion is prepared as a part of the research project 'Romalnterbellum. Roma Civic Emancipation between the Two World Wars' which has received funding from the European Research Council under the European Union's Horizon 2020 Research and Innovation Programme (grant agreement No. 694656) with Principal Investigator Prof. Elena Marushiakova. It reflects only the authors' view, and the agency is not responsible for any use that may be made of the information it contains.

\section{References}

Chernykh, A. V. (2020). The Kalderash Gypsies of Russia in industrial cooperation of the 1920s-1930s. Social Inclusion, 8(2), 358-366.

Eisenstadt, S. N. (2000). Multiple modernities. Daedalus, 129(1), 1-29.

Gontarek, A. (2020). Political activity of Kwiek 'Dynasty' in the second Polish Republic in the years 1935-1939. Social Inclusion, 8(2), 336-345.

Hajnáczky, T. (2020). Hungarian Gypsy Musician's National Association: Battles faced by Gypsy musicians in Hungary during the interwar years. Social Inclusion, 8(2), 327-335.

Hancock, I. (2010). Danger! Educated Gypsy. Selected essays. Hatfield: University of Hertfordshire Press.

Hechter, M. (1975). Internal colonialism. The Celtic fringe in British national development. London: Routledge.

Jusdanis, G. (1991). Belated modernity and aesthetic culture. Minneapolis, MN: University of Minnesota Press.

Marinov, A. G. (2020). Images of Roma through the language of Bulgarian state archives. Social Inclusion, $8(2), 296-304$.

Martin, T. (2001). The affirmative action empire: Nations and nationalisms in the Soviet Union 1923-1939. Ithaca, NY: Cornell University Press.

Marushiakova, E., \& Popov, V. (2018). Roma labelling: Policy and academia. Slovenský Národopis, 66(4), 385-418.

Marushiakova, E., \& Popov, V. (2020). 'Letter to Stalin': Roma activism vs. Gypsy nomadism in Central, SouthEastern and Eastern Europe before WWII. Social Inclusion, 8(2), 265-276.

Matei, P. (2020). Between nationalism and pragmatism: The Roma movement in interwar Romania. Social Inclusion, 8(2), 305-315.

Ploscariu, I. (2020). Faith Church: Roma Baptists challenging religious barriers in interwar Romania. Social Inclusion, 8(2), 316-326.

Roman, R. (2020). From Christian mission to transnational connections: Religious and social mobilisation among Roma in Finland. Social Inclusion, 8(2), 367-376.

Said, E. (1995). Orientalism: Western conceptions of the Orient. Harmondsworth: Penguin.

Šarenac, D. (2020). A view of the disaster and victory from below: Serbian Roma soldiers, 1912-1918. Social Inclusion, 8(2), 277-285.

Shapoval, V. (2020). 'The books to the illiterate?': Romani publishing activities in the Soviet Union, 1927-1938. Social Inclusion, 8(2), 346-357.

Todorova, M. (2005). The trap of backwardness: Modernity, temporality and the study of East European nationalism. Slavic Review, 64(1), 140-164.

Todorova, M. (2009). Imagining the Balkans. New York, NY: Oxford University Press. 
Zahova, S. (2020). "Improving our way of life is largely in our own hands": Inclusion according to the Romani newspaper of interwar Yugoslavia. Social Inclusion, 8(2), 286-295.

\section{About the Authors}

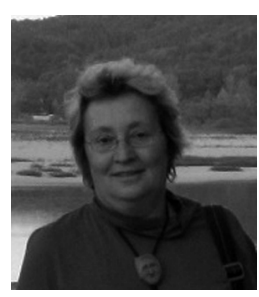

Elena Marushiakova, Professor at the School of History, University of St Andrews, works in the field of Romani studies for more than four decades and published widely on Roma in Central, Eastern Europe and Southeastern Europe and Central Asia. She is the principal investigator in the research project 'Roma Civic Emancipation Between the Two World Wars' (ERC Advanced Grant 2015, No. 694656). Elena Marushiakova is President of the Gypsy Lore Society, which is the world's oldest organization in field of Romani studies.

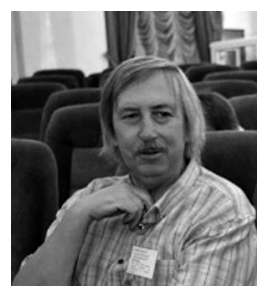

Vesselin Popov, Professor at the School of History, University of St Andrews, works in the field of Romani studies for more than four decades and published widely on Roma in Central, Eastern Europe and South Eastern Europe and Central Asia. Currently Prof. Vesselin Popov is conducting research in frames of ERC Advanced Grant entitled 'Romalnterbellum. Roma Civic Emancipation Between the Two World Wars.' 